Open Access

\title{
House, state, and world fundamental concepts of societal governance in the West and East in comparison
}

\author{
Wolf Rainer Wendt(10
}

\author{
Correspondence: prof.dr.wendt@ \\ gmail.com \\ Stuttgart, Germany
}

\begin{abstract}
In the development of civilizations from antiquity to the present day, two institutions can be identified which, in their relationship to one another and in their relation to a comprehensive order, shape the cohabitation of people and individual existence. In the occidental context they are the institutions (in Ancient Greek designation) Oikos and Polis and the order framework of the Kosmos. In the East Asian context there are in the same fundamental sense the Chinese terms Jia, Guo und Tianxia. The use of these terms has varied, but the categorical relationships of what they denote found the societal design and legitimize modes of societal governance. It seems necessary to be clear about the basic concepts and organizational patterns in worldwide exchange. A comparative interpretation of those concepts and patterns reveals the differences in western and eastern societal statics and dynamics in the past and today. The study of the common features with different characteristics leads to considerations on a global level as to societal governance can be sustainable.
\end{abstract}

Keywords: Societal governance, Oikos, Polis, Kosmos, Jia, Guo, Tianxia, Greek philosophy, Confucianism
At the same time, two and a half thousand years ago in the so-called "axial age" (Jaspers 1950, 19), the fundamental concepts of the household system, the state system and the basic idea of a world order, unfolded into an overarching concept that legitimizes the relationships within and between those institutions, emerged independently of one another in the West in Greece and in China in the East. In the spheres of the household, the statehood and the ordered world common existence is maintained and further developed in structure and function. Those entities and spheres constitute societal institutions within which life and the activities of people are shaped and can develop. Societal governance concerns the mutual interaction, guiding and influencing in and between the entities and spheres. The present article discusses the meaning of the

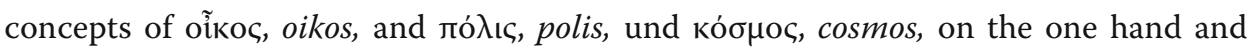
of 家, jia, 國, guo and 天下, tianxia on the other, as they emerged, were repeatedly taken up and modified. It is about fundamental patterns of life organization, social care, social security and the system of political rule and administration.

(c) The Author(s). 2018 Open Access This article is distributed under the terms of the Creative Commons Attribution 4.0 International License (http://creativecommons.org/licenses/by/4.0/), which permits unrestricted use, distribution, and reproduction in any medium, provided you give appropriate credit to the original author(s) and the source, provide a link to the Creative Commons license, and indicate if changes were made. 


\section{From the roots: The domestic and the political regime}

People do not live alone and their coexistence requires order. The life of a sedentary person is organized and regulated in and around a household. In it the existence of the individual person is embedded and in it the common existence of people is maintained. In the West, the antic oikos was the entity of a co-resident domestic group, their housing and their courtyard. The process of householding in the oikos includes all the economic and social dispositions and caring activities to sustain the livelihood and to reach and to maintain the well-being of the members of the household. The oikos is the original pattern and the general form of a structure of care and of organized conduct of life.

Aristotle determined in the Book 1 of Politics that the household is natural to man. He lives in the oikos in a partnership "that comes about in the course of nature for everyday purposes" (Arist. Pol. 1252 b 13). The persons in the oikos are "meal-tub-fellows". The oikos is not founded on kinship among the people who belong to it. The co-resident domestic group included dependents, slaves and employees. We have to distinguish between the concepts of household and family in the West (Cox 1998, $130 \mathrm{ff}$.).

A house does not stand alone; the primary partnership made up of several households for the satisfaction of not mere daily needs is the village. It is originally only an extended clan. The polis was an urban settlement to which the oikoi respectively their rulers came together (cf. Welwei 1998, 35 ff., cf. Hansen 2006). "The partnership finally composed of several villages is the polis; it has at last attained the limit of virtually complete self-sufficiency, and thus, while it comes into existence for the sake of life, it exists for the good life." (Arist. Pol. 1252 b 25-30) The polis came into being for economic reasons. In it, the agora was a marketplace for trade - and it was a meeting place where democracy could at times be practiced. It was appropriately discussed whether the political community was constituted by a simple agreement or by a contract between free men. (Müller 1987, 53 ff.) Aristotle argued against this individualistic position (Arist. Pol. 1280 b 31-35):

"It is manifest therefore that a state is not merely the sharing of a common locality for the purpose of preventing mutual injury and exchanging goods. These are necessary preconditions of a state's existence, yet nevertheless, even if all these conditions are present, that does not therefore make a state, but a state is a partnership of families and of clans in living well, and its object is a full and independent life."

Over time, a horizontal extension of the institutional order has emerged: from individual oikonomikos as skilled household manager (Xenophon) or oikonomos in the domestic sphere to membership in the polis (and in modernity to citizenship in the state). In fact, the ancient Greek polis was basically a company of citizens; it deserves to be called a "citizen-state", organized in a distinction between citizens who monopolize power, "share among themselves the incumbency of central government roles, and who subscribe to an ideology of mutual respect, and non-citizens, the product of whose labour is controlled by the citizens." (Runciman 1990, 348).

The polis is the mode of existence of a citizen as a free man; therefore man belongs to the political community. He is a zoon politicon (Arist. Pol. 1253 a 1). As such, the man appears in the polis as an individual and asserts himself as an individual in the 
community. Equipped with an oikos, the man together with other man constitutes the polis as a "community of freemen" (Arist. 1279 a 21). For human exchange and the true perception of good and bad and right and wrong, the polis "is prior in nature to the household and to each of us individually. For the whole must necessarily be prior to the part" (Arist. Pol. 1253 a 20).

Aristotle distinguished between the regime of oikonomos in the household and the regime of politikos, a "statesman" in the polis as far as the mode of rule was concerned (cf. Nagle 2006). Before Aristotle, Plato had seen no difference between the two regimes. In the dialogue Politikos ( 259 c) he makes one ask: "a large household may be compared to a small state: will they differ at all, as far as government is concerned?" The answer is: "They will not." So there would be "one science of all of them; and this science may be called either royal or political or economical; we will not quarrel with any one" (transl. Jowett 1892).

If we look at the householding and political regime in ancient China in parallel to the constitution of Oikos and Polis in Greek antiquity, it should be borne in mind that the mode of thinking and use of language in Chinese differs from that in the West. In regard to our topic, it is not fixed objects that are compared, but action areas that are in motion from the outset. In their discussion of translation problems, Ames and Hall (2001) therefore recommend to consider terms as a focusing of a field of meaning that can only be understood approximately and not definitively. Presumed is" a world constituted by an interactive field of processes and events in which there are no final elements, only shifting 'foci' in the phenomenal field, each of which focuses the entire field from its finite perspective" (Ames and Hall 2001, 7).

Therefore, more is implied than is named. This also applies to Western terms such as household and res publica, but much more to the relevant Chinese characters. We have to interpret the terms 家, jia, and 國, guo. At first glance, their semantics are consistent with the sense of the relevant Greek terms. Jia means house and family; guo means a political unit. The character 家 depicts a pig under a roof and thus indicates the economic function that is fulfilled in the house for a living. Jia is the place where a family lives. It embodies the proper order of life (Schaaf 2001). In the same sense, in Japanese, the term ie means the house and its inhabitants, relatives and not relatives. "The $i e$ is a corporate residential group and, in the case of agriculture or other similar enterprises, $i e$ is a managing body" (Nakane 1970, 4).

Just as the word "house" has been used over time in Europe in various contexts of meaning (not least politically for a ruling house), in modern times jia has become a component in many Chinese terms. It stands, for example, for a school of thought (儒 家, ru jia, Confucianism), designates the expert as "smart house", 专家, zhuan jia, or an important person as "great house", 大家, da jia. Jia also has a public connotation in this language usage. While in the western context the unity of the house with its inhabitants remains private and not public, the relationship of jia to the political sphere is quite different in the East.

There is a systematic subordination of small communities to the larger community and the state. The small units are particles of the large unit. There has always been a household registration system, 户口制度, hùkǒu zhìù, in China (and elsewhere in East Asia) as a control structure. (Wang 2005, Young 2013). The "work unit", 單位, danwei, has long been the smallest residential and production unit with many care, control and supply functions in the People's Republic of China (Lü and Perry 2015). 
Initially there was in China in the territory of clans an equation of the sphere of action of jia and the domain of 國, guo. The head of the clan could also be ruler of land and people. The character 國 shows the meaning of a territorial unit; originally also in the sense of a manorial house or family, which is feoffed with land (Gassmann 2006, $258 \mathrm{ff}$.). In this respect, the expressions guo and jia partially overlappe. The manageable baronies could be governed in a familiar manner. The Confucian approach of political theory in the late Zhou period, during which Confucius lived, discusses the linking of guo and jia in the "Great Learning", Da Xue:

"The ancients who wished to illustrate illustrious virtue throughout the kingdom, first ordered well their own states. Wishing to order well their states, they first regulated their families. Wishing to regulate their families, they first cultivated their persons. Wishing to cultivate their persons, they first rectified their hearts. Wishing to rectify their hearts, they first sought to be sincere in their thoughts. Wishing to be sincere in their thoughts, they first extended to the utmost their knowledge. Such extension of knowledge lay in the investigation of things. Things being investigated, knowledge became complete. Their knowledge being complete, their thoughts were sincere. Their thoughts being sincere, their hearts were then rectified. Their hearts being rectified, their persons were cultivated. Their persons being cultivated, their families were regulated. Their families being regulated, their states were rightly governed."

(Legge 1985, $357 \mathrm{ff}$.) A line can be drawn from this connectivity of action regulation in the bodies of singular and common households or states towards the ongoing identification of family and state in the East.

In the West, the individual remains the political actor both inside and outside the home. There is to the Confucian text an analogy in Aristotle's "Politics", which elaborates on the internal relations between the members of a household:

"Inasmuch as every family is a part of a state, and these relationships are the parts of a family, and the virtue of the part must have regard to the virtue of the whole, women and children must be trained by education with an eye to the constitution, if the virtues of either of them are supposed to make any difference in the virtues of the state. And they must make a difference: for the children grow up to be citizens, and half the free persons in the state are women."

(Arist. Pol. 1260 b 13-20, transl. Jowett 1892) While Aristotle focuses on the training of citizens as free actors, in the Chinese context the integration of actors into the political and domestic bodies with their (ritual) requirements remains constant over time. There is a vertical depth of embedding. The holistic integration includes the fact that there can be no clear distinction between private and public life. Consequently, the relationship of guo and jia „was primarily a distinction of subjects' belonging and not conceived as a distinction between an open, public realm and a personal, private realm. Rather, it was a relation of flexible expansion and contraction. "(Tang 2004, 12) Belonging in the family and in the state leaves the individual little or much freedom, but it does not discharge him or her. Individuals remain "actors in relations". 


\section{Kosmos as the world order}

The conduct of life in households and the leadership of a state need order and legimitation in the West as well as in the East. How the world is organized is comprehended in the Greek concept of the cosmos. The word kó $\mu$ os, kosmos, is already found at Homer in the meaning of order, ordering, arrangement (cf. Kerschensteiner 1962). In philosophical reasoning the term kosmos, the same of all, first appears in Heraclitus (Kahn 1979, 131 ff.) and in other early Greek philosophers. The use of the term also extended to the office of those who had to maintain order. In the early Greek poleis there were elected kosmoi as stewards who formed a council and dispensed justice. "Cosmic" is a well-disposed and well-prepared state of affairs.

The philosophical term kosmos refers to a well-ordered universe, to its harmonious constitution and its spatial and temporal extension. Pythagorean is the idea of a harmony of spheres. The concept of the cosmos is the antithesis to chaos. In the discussion of the kosmos the term has undergone different connotations. With Plato it is found in the meaning "order of life". A social sense assumes it when it designates the appropriate form in dealing with people. (Gatzemeier 1976, 1167) Heraclitus already connected the regularity of the course of the world with the order of human matters (Kerschensteiner 1962, 110). Kosmos names the world of people and the physical uni-

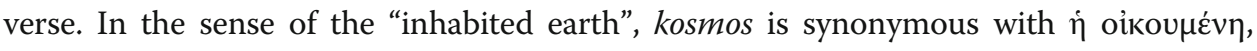
oikoumene. As the home of all (denominational) communities, Christian ecumenism forms a worldwide unity. The religious interpretations of kosmos are manifold.

The concept of the cosmos has become significant in Stoic philosophy. Zenon of Kition, the founder of the Stoa, speaks in his Politeia of the unity of life and cosmos. For the Stoics, the cosmos is the system of heaven and earth with its associated life forms (cf. Wildberger 2006, 244). In this system, man can become a citizen of a world state with all the obligations that participation in it entails. (Zenon has probably thought of a free association of settlement communities, cf. Müller 1987, 281) Thus kosmos becomes a political concept: in the Roman Empire the whole human community can be understood as a homogeneous and at the same time diverse one, encompassed by the polis of Rome and composed of many poleis (Richter 2011, 4).

When the words kosmos and polite, the citizen, merge, the term "cosmopolitan" comes into being. The Greek Cynic Diogenes was the first to call himself a citizen of the world. He claimed to be without house and home and not tied to any polis. The undemanding independent existence that the Cynic claimed for himself meant less to be at home throughout the world, more to be homeless and to remain a stranger, at least an outsider, everywhere. A positive cosmopolitanism may mean that modern people can be at home anywhere. But he or she will not yet become a citizen of one world. World citizenship is about bonds and commitments, both local and global.

The great power structures in Hellenism and the Roman Empire called into question the relationship between citizens and community, between man and the world. The Stoics compared the cosmos in its ideal order with the real political conditions. In Seneca the cosmic res publica is free from the grievances of the reign of his time. The cosmos itself appeared to him as a "world state". It could be a "state that is common to gods and people" (Wildberger 2006, 246). May man withdraw from real political affairs, as Seneca did; as a citizen of the world, the cosmos remains his home. This is where his life is based, and even without a political office he has an obligation to work in it 
sensibly with his ability to think and act. The homeliness and the tasks in the world reflect the shelter and the tasks in the oikos; politics seems to be an intermediate way of fulfilling these tasks. Only house and world are elementary.

\section{The order under heaven}

All encompassing the order of the world in the concept of the cosmos is meant in Chinese 天下, tianxia, "under heaven everything”. As in the Greek expression, the key term tian combines many connotations (cf. Lan and Jia 2016). 天, tian, describes the overarching orientation of all action, the cultural order of existence, the world in the physical sense and the Guo, which is expanded to the borders of the world - and therefore also equals the concept of oikoumene in content (cf. Weber-Schäfer 1968, 224). The cosmic space is tuned harmoniously and resonantly. In many early texts there is an association with music (Brindley 2013, 7 ff.). Similar to the Greek idea of harmony in the cosmos, the Confucian doctrine interprets tian "musically" and according to it a ritually appropriate state leadership and the common conduct and personal way of life. As in the West the Stoics interpreted the cosmos as a natural order, tian, "heaven", is often and for good reasons translated as "nature" (Knoblock 1994, 3; Machle 1993, 1 ff.).

Zhao Tingyang, whose political philosophy is yet to be addressed, comments:

“The term 'All-under-Heaven' (Tian-xia), found in almost the oldest Chinese texts, means firstly the earth, or the whole world under heaven. It is almost equivalent to 'the universe' or 'the world' in western languages. Its second meaning is the 'hearts of all peoples, or the 'general will of the people'. The world is always the home-forpeople, that is, the earth as it is ours more than the earth as it is. All-under-Heaven therefore consists of both the earth and the people. Consequently, an emperor does not really enjoy his empire of All-under-Heaven, even if he conquers an extraordinary vastness of land, unless he receives the sincere and true support from the people on the land. Just as philosopher Xunzi (313 B.C./238 B.C.) said in his essay 'On kingship and supremacy':

Enjoying All-under-Heaven does not mean to receive the lands from people who are forced to give, but to satisfy all people with a good way of governance."

(Zhao 2006, 29). Tianxia has existed as a political concept since the times of the Zhou dynasty (c. 1100-256 B.C.) when the aim was to establish a unified rule over different tribes and kingdoms. Tianxia legitimized rule over "everything under heaven" in its commonness in a large household in which the earth with its inhabitants must be kept in order under heaven. The ruler has the "mandate of heaven" if he and as long as he succeeds in fulfilling that task.

The overarching concept is inclusive; all lands and all people are equally involved. In its ideal design, tianxia represents a framework for coexistence and its stewardship." As a cosmological ordering of the world under heaven, tianxia also concerned Self and Other relations-not only in the sense of inter-cultural relations, but also in the sense of cosmo-political alterity (i.e., internal, external, and intermediary others)" (Wang 2012, 338). In a moral sense, tian, heaven as "top of the head" is what guides people in life above their heads. Ideally, the unity of heaven and humanity is achieved in the 
ethos of man. The common notion and Confucian principle 天人合一, tian-ren-he-yi, means a harmonious unity of heaven and the human (cf. Li 1999, Yü 2016, 1 ff.). As Xunzi says, 天人相分, tian ren xiang fen, the separation, the breakup of heaven and man must be avoided.

The idea of tian-ren-he-yi can be elaborated to an "eco-ethical" approach (Yao 2014). In its complex sense, the concepts of tian and tianxia were discussed in Neo-Confucianism and then in the course of China's modernization. Ecologically considered, the tianxia principle claims the person-in-environment. The self of man includes the world as it includes man. In the words of the neo-confucian Wang Yangming: "The exemplary person regards Heaven and Earth and the myriad things as one body" (Zhang 2017, 341). By the way, following Neo-Confucianism, it is argued that "cosmos" is an appropriate translation of tian (Angle 2018).

\section{Society intervenes in the relation of state, family, and person}

In the nineteenth century, when the political and social models from the West were perceived in East Asia, they first had to be translated by the protagonists of change into their own patterns of thought and practice. In the process of forced modernization in Japan during the Meiji period after 1868, it followed to identify the new statehood with the traditional sense of family (ie). Accordingly, in China the term guojia was chosen to designate the state - while da Qing guo, state of the Great Qing dynasty, was still officially used (Lackner 2004, 327). In Japan the state-family was constructed with the emperor in the center. All societal relations from the members of the house (ie) to the state leadership were structured hierarchically according to the principles of Confucian ethics. For societal governance, a "bureaucratic ethos" emerged, which determined the relations between political parties and government. (McVeigh 1998, 44 ff.) What society should be anyway, this clarification has been a difficult task.

The Western idea of a free association had no genuine basis in East Asia. To this day, Japanese define and behave according to their situational position in a particular frame (Nakane 1970, 2). Group membership and the group nexus dominate over autonomy. "Japanese uses the expression uchi (my house) to mean the place of work, organization, office or school to which he belongs" (Nakane 1970, 3) When "freedom" was translated into Japanese, jiyu (with the same characters as tzuyu in Chinese) was used, which meant "selfishness" - with negative connotations in Chinese and Japanese tradition. The interpreters were aware of the inadequacy of the translation. Misunderstandings were inevitable. "When Nakamura Masanao published his translation of John Stuart Mill's On Liberty in 1872", he "could not understand the distinction between »society« and »government«. In chapter four of On Liberty, where Mill talked about society's control over an individual, Nakamura understood it as a problem between government and the individual. In the same way »collective opinion « was translated as »the government's opinion.«." (Ishida 1987, 307).

In a very rough understanding, society is a large group of people who live together in an organized way. Humans differ from animals in that they are capable of community or group, 群, qun. Xunzi had already found that. Initially, "society" could also be represented in Chinese with qun. (Vogelsang 2012, 163 f.) But in 1877, the Japanese government chose the binominal phrase 社会, shakei for the official translation of the Western term "society". Shakei was of Chinese origin with the former meaning of a religious gathering of villagers at 
local shrines. Society, understood as the association of independent citizens in pursuit of their interests and to express their will, was not among the connotations of the binom 社 会, Chinese shehui. In their modernization efforts Chinese reformist intellectuals (re)imported the expression a little later (Tian 2014, 43). For the reformers seemed the suitability of the term (in the sense of a large common group) doubtful to express the unity of the Chinese nation as a society, even democratic society in the future. One had to have a concept of the citizen to understand society in the Western sense. At the end of the nineteenth century, the reformers Kang Youwei and Liang Qichao chose 国民 guomin (people of a state), emphasizing the citizens' nationality and thus their belonging to a nation-state that the reformers identified with a modern state (Harris 2002, Guo 2015, 5 ff.).

Now it must be emphasized: In the political sense, society in Europe has been an innovation of the modern age, intervening between the old concepts of Oikos and Polis. It was an innovation of citizens who, outside the home and independent of political domination, ran their businesses. The evolution of society in the West was preceded by the constitution of the modern state, in turn a reaction to the independence and arbitrary action of individuals in early modernity. They replaced dependence by "always going it alone" or individual souvereignty. In Europe, the Reformation was a particularly momentous manifestation of a considered and founded arbitrariness - with the consequence of the religious wars. They finished with the Westphalian system of statehood, characterized by authority based on territory, not on identity of the people (cf. Krasner 2009).

The state was a "technical invention" (Bubner 2002, 104). According to Thomas Hobbes (in his "Leviathan", 1651), the enforcement of order over individual arbitrariness required the power of the state. The sovereignty of the state thwarts the sovereignty of the individual in its own interests. The relationship between private action and state policy is therefore a contradictory one in the West from the very outset. The enforced state is opposed by the individualistic postulate that the state can only be a continuous result of the will and actions of its citizens. Quite different is a preexistant guo or an organically founded state. It is not compatible with the "calculus of consent" of individual citizens. "The organic State has an existence, a value pattern, and a motivation independent of those of the individual human beings claiming membership. Indeed, the very term 'individual' has little place in the genuinely organic conception; the single human being becomes an integral part of a larger, and more meaningful, organism." (Buchanan and Tullock 1962, 11).

\section{Intermediary societies and the late appearance of the social}

In the West, citizens became sociable in joint undertakings. In the Age of Enlightenment after 1700, associations and fellowships of citizens emerged all over Europe, who devoted themselves patriotically and economically to local interests in a sphere below of their political domination. These societies built up a network of relationships in addition to the business relationships of their members. Their social activity supplemented their economic activity. It is remarkable that the word "social" came into use not before the publication of Rousseau's "Contrat social" in 1762. The Encyclopédie of the French Enlightenment recorded the word "social" in 1765 as "a word recently introduced in language to designate the qualities that make man useful in society or fitting for the commerce of men". The Oikos of citizens was dissolving into the space of their outer activities, releasing, on the one hand, economic action into the market exchange and, on 
the other hand, tasks of care and supply into the public space, which the citizens filled with their societies.

Society, according to its genesis in the West, is not the space of family relationships and bonds in which man nolens volens is embedded. In the free association of citizens without a directing authority there is a tradition of egalitarianism in Western civil society, while in Confucian tradition people are treated as relatives and not as equals (Fan 2010, $28 \mathrm{ff}$.) In the West the private sphere of life is neutralized in the civil public. This is above all a sphere of free communication and the formation of public opinion. The state and its organs are not shareholders in the societies (although in the eighteenth century the secret societies of the Freemasons built a bridge to state affairs). Today's civil society consists mainly of non-governmental organizations. It is understandable that their development in East Asia (in the tradition of a "state family") is difficult.

The multitude of societies in the Age of Enlightenment disappeared with the French Revolution. There should only be one social body left: the nation. All people within the national territory belong to it without being members of a special association. The social body could be identified with the state as the body politic after the sinking of the Ancien regime. The nation state gradually took on social tasks in Europe and formed a welfare regime from them in the twentieth century. The "social" appears in him only as a differentiation of caring and supply functions. However, in the democratic state of citizens, "society" remains as its counterpart. Societal governance can evolve in the interaction between the state and civil society.

In the East, there is a different kind of the "social": A frame of belonging and a structure of relationships in which people are interwoven and which form their personal network. In this "different mode of association" (Fei 1992, 71), the social appears in a web of interrelatedness as a composite of networks, not as a concrete and ultimately abstract association of persons. The self of each person is interdependent in relationships with others (Markus and Kitayama 1991, 226). "Actors are related to each other and also to the context, or the totality of their relational circles. It indicates a context-oriented society: Things, persons, and events coexist in the complex relational context, without which none of them would exist at all." (Qin 2016, 35) The connectedness does not prevent the pursuit of diverse interests. Significant for that kind of being related is the Chinese term 關係, guanxi. (Gold et al., 2002) Unlike social practice in the West, Guanxi does not neutralize the personal and private, on the contrary: in his or her relationships one is familiar, can trust and gains trustworthiness, 信用, xinyong, i. e. credit with others and in the public. In it, the state or the "state family" can build on the obligations of the citizens and tie its obligations to them in ways of societal governance.

\section{Order in life and in the common world}

In Chinese tradition, societal relationships are ruled by morals and rituals. Personal obligations are not one-sided if they consist in the commonality of rituals. Ritual propriety, 礼, 禮, $l i$, interconnects the harmonious relations between persons, within families, within the state and "under heaven everything". Without referring to a concept of society, the Confucian philosophy seeks to achieve consistency (harmony) through mutual regulation of action in state and family. $L i$ turns communication and the societal space into 
a harmonious one. Selfishness and ego-centeredness are excluded from the ritualized space of relationships. In the Warring States period in China, Xunzi justifies 禮, $l i$, the ritual principles in their function of order for the government of the guo and the self-governance of men:

"How did ritual principles arise? I say that men are born with desires which, if not satisfied, cannot but lead men to seek to satisfy them. If in seeking to satisfy their desires men observe no measure and apportion things without limits, then it would be impossible for them not to contend over the means to satisfy their desires. Such contention leads to disorder. Disorder leads to poverty. The Ancient Kings abhorred such disorder; so they established the regulations contained within ritual and moral principles in order to apportion things, to nurture the desires of men, and to supply the means for their satisfaction. They so fashioned their regulations that desires should not want for the things which satisfy them and goods would not be exhausted by the desires. In this way the two of them, desires and goods, sustained each other over the course of time. This is the origin of ritual principles."

(Knoblock 1994, 55) Like Hobbes in the West, Xunzi thinks people are evil by nature. Desires must be overcome in the discipline of ritual action. Man governs himself und is cultivated in it. The proper conduct of personal life is a question of culture in the expression of ritual propriety. As in early China, self-governance is called for in East Asia from Singapore to Korea today so that societal governance in the fields of education, social policy and economic life is successful (cf. on self-governance as a mode of societal governance: Kooiman and Van Vliet 2006; on the cardinal role of rituals in social life: Fan 2010).

A person searches for an inner agreement in self-governance; a state is dependent on an inner agreement in the actions of its actors. Therefore, a state authority and administration strive to adjust personal self-governance, societal and political intentions to each other. It is a quest for harmonization, at best directed towards a higher (or cosmic) order given in tian, towards maintaining a balance as described in the Confucian "Doctrine of the Mean",中庸, Zhongyong (a chapter in the Book of Rites, in the new translation by Ames and Hall 2001 titled as "Focusing the Familiar"). Whoever goes the "middle way" achieves an equilibrium and harmony and yet can flexibly follow a change that must once again maintain balance in the field of its references.

The Chinese ideal of 和, he, harmony, is often misunderstood in the West. »In Chinese theory, harmony is the necessary ontological condition for different things to exist and develop, "usually defined as reciprocal dependence, reciprocal improvement or the perfect fitting for different things, as opposed to the sameness of things" (Zhao 2009,14). In other words, "harmony is an elegant order that emerges out of the collaboration of intrinsically related details to embellish the contribution of each one" (Ames und Hall 2001, 66). In early Chinese texts he "mostly has to do with sounds and how sounds interact with one another ... how various sounds - of animals, of people and of instruments - respond to one another. This meaning of 'responding' is preserved in the modern Chines language, when he is used as a verb." (Li 2006, 583). In the sense of "harmonizing" he has a processual and dynamic character. In politics, the term is often used to indicate that projects are on the right track and lead to a consensus on desirable goals (Rosker 2013). 
In a balancing function and in the broad horizon of tianxia, "the middle way" also seems suitable for overcoming global differences and disputes. Unlike the nation states of the West, China as 中国, Zhongguo (although this is a modern term), has drawn no boundaries under tian and identified itself with the world in tianxia. In this understanding, Zhao Tingyang from the Chinese Academy of Social Sciences has undertaken to propose a future shape of transnational relations in the conceptual framework of tianxia (Zhao 2005, 2006, 2009, 2012). In the meaning of tianxia, Liang Qichao had already distinguished two interpretations in 1899: “(1) tianxia meant - the world 世界 (shijie), understood to comprise all the realms on earth, and as such, it referred to a kind of polity radically different from the nation; and (2) tianxia not only meant a different polity from the nation - which, as Liang rightly pointed out, was a European invention - but it also implied certain conceptions of the world 世界思想 (shijie sixiang)" (Wang 2012, 337 f.). This second approach can now be turned ethically and ecologically. "As an antidote to self-centered individualism and hostile clashes between nation-states and civilization" by Zhao Tingyang the accent is "placed on interdependence over atomistic independence - where interdependence governed all levels of sociality, from family to larger community to the 'world' as a whole" (Dallmayr 2012, 5). Tian xia excludes "nothing and no one". On this concept could build a political philosophy of the world and one could transform the politics of nationalism into a global governance based on harmony and cooperation without hegemony:

"The difference between philosophy for the world and philosophy of the world is very relevant to the justification of a world-view. Anybody can have a world philosophy in accordance with his own horizons. Likewise, any nation can have a world philosophy in keeping with national interests. However, we need a world philosophy which speaks on behalf of the world. The world is absent because of our refusal to see it from its own perspective. The failure of world politics is essentially the failure of philosophy. The question is therefore how to take care of the world for the world?"

(Zhao 2009, 7). This global perspective aims at a practice against the dictum of the current Trump administration, "that the world is not a 'global community' but an arena where nations, nongovernmental actors and businesses engage and compete for advantage" (McMaster and Cohn 2017). Where everyone fights for themselves and against everyone, the result is chaos. Zhao's concept is oriented towards a global inclusion of the actors, recognizing their diversity within the framework of overarching global interests. The claim from China for a new global relationship or political oikoumene has been much discussed in recent years (Callahan 2008, Wang 2017). Such thought and reflections, however one may stand by them, show to what extent the key concepts discussed with their long tradition are still suitable today as a blueprint for social and political projects.

\section{Conclusion}

All the categories studied have a variety of connotations and connections in their field of meaning with which current problems in society and politics can be connected locally and worldwide. Oikos can be the basic ecological pattern of responsible and sustainable economic activity in a global context and with a view to shaping social and solidarity care for today and tomorrow. Polis and guo are two contrasting basic patterns 
of political rule and societal governance. While in the West the res publica stands out from the private sphere of life, in the East the personal lifestyle remains embedded in the sphere of communities. Different realizations of democracy, law, economic regulation and social policy are the result. The principles of kosmos and tianxia agree on the overarching and profound role of order in the world, in the polity, in households and in individual action. However, the order of values appears to be differently pronounced and to a lesser or greater extent and with different varying qualities established.

In a comparative perspective, the common features with different characteristics present societal governance with a wide and multidimensional scope. On the personal level, the shaping of individual conduct of life in divergent frames of reference is under consideration. Men act in relational reasoning according to cultural patterns. On a social level, the question arises of how individualization in the digital age can be strengthened or bound by networking. In the welfare regime, decisions must be made on arrangements for individual self-help and common care with public provision. At the macro level of politics, responsibility for the infrastructure of societal prosperity is linked to the superstructure in the value horizon of polity. After all, the most relevant relation in which we must think and act is global sustainability. Despite all the divergences in societal governance, global sustainability can only be achieved through convergent cooperation between the East and the West.

Abbreviation

Arist. Pol. 1252 b 13 et al.: Bekker census of Aristotle's works

Availability of data and materials

All data generated and/or analyzed during this study are included in this published article.

Author's contributions

I am the only author and copyright owner. The author read and approved the final manuscript.

Competing interests

The author declares that he has no competing interests.

\section{Publisher's Note}

Springer Nature remains neutral with regard to jurisdictional claims in published maps and institutional affiliations.

Received: 9 July 2018 Accepted: 15 August 2018

Published online: 29 August 2018

\section{References}

Ames, Roger T., and David L. Hall. 2001. Focusing the familiar. In A translation and philosophical interpretation of the Zhongyong. Honolulu: University of Hawaii Press.

Angle, Stephen C. 2018. Tian as Cosmos in Zhu Xi's neo-Confucianism. Dao. A Journal of Comparative Philosophy 17 (2): 169-185.

Brindley, Erica Fox. 2013. Music, cosmology, and the politics of harmony in early China. Albany, NY, State University of New York Press.

Bubner, Rüdiger. 2002. Polis und Staat. Grundlinien der Politischen Philosophie. Frankfurt am Main: Suhrkamp.

Buchanan, James M., and Gordon Tullock. 1962. Calculus of Consent. Logical Foundations of Constitutional Democracy. Ann Arbor, MI, University of Michigan Press.

Callahan, William A. 2008. Chinese Visions of World Order: Post-hegemonic or a New Hegemony? International Studies Review 10 (4): $749-761$.

Cox, Cheryl Ann. 1998. Household Interests. Property, Marriage Strategies, and Family Dynamics in Ancient Athens. Princeton, NJ: Princeton University Press.

Dallmayr, Fred. 2012. Introduction. In Contemporary Chinese Political Thought. Debates and Perspectives, eds. Fred Dallmayr, and Tingyang Zhao, 1-16. Lexington: University of Kentucky Press.

Fan, Ruiping. 2010. Reconstructionist Confucianism. In Rethinking Morality after the West. Dordrecht: Springer.

Fei, Xiaotong. 1992. From the Soil. The Foundations of Chinese Society. Berkeley, CA. University of California Press.

Gassmann, Robert H. 2006. Verwandtschaft und Gesellschaft im alten China. Begriffe, Strukturen und Prozesse. Bern: Peter Lang.

Gatzemeier, Matthias. 1976. Kosmos. In Historisches Wörterbuch der Philosophie, vol. Band 4, 1167-1173. Darmstadt: Wissenschaftliche Buchgesellschaft.

Gold, Thomas, Douglas Guthrie, and David Wank. 2002. Social connections in China: Institutions, culture and the changing nature of Guanxi. Cambridge: Cambridge University Press. 
Guo, Zhonghua. 2015. The emergence of the citizen concept in modern China: 1899-1919. In: Theorizing Chinese citizenship, eds. Zhonghua Guo, and Sujian Guo, 3-23, Lanham, MD: Lexington Books.

Hansen, Mogens Herman. 2006. Polis. An introduction to the ancient Greek City state. Oxford: Oxford University Press. Harris, Peter. 2002. The origins of modern citizenship in China. Asia Pacific Viewpoint 43 (2): 181-203.

Ishida, Takeshi. 1987. The Introduction of Western Political Concepts into Japan: Non-Western Societies' Response to the Impact of the West. In Wissenschaftskolleg - Institute for Advanced Study - zu Berlin: Jahrbuch 1986/86, 305-312. Berlin: Siedler.

Jaspers, Karl. 1950. Vom Ursprung und Ziel der geschichte. München: Piper.

Jowett, Benjamin. 1892. Plato, the dialogues of Plato translated into English with analyses and introductions by B. Jowett, M.A. in Five Volumes. 3rd ed. Oxford: Oxford University Press.

Kahn, Charles H. 1979. The art and thought of Heraclitus. An edition of the fragments with translation and commentary. Cambridge: Cambridge University Press.

Kerschensteiner, Jula. 1962. Kosmos. Quellenkritische Untersuchungen zu den Vorsokratikern. München: C.H.Beck.

Knoblock, John. 1994. Xunzi. A translation and study of the complete works. Volume III, books 17-32. Stanford: Stanford University Press.

Kooiman, Jan, and Martijn Van Vliet. 2006. Self-governance as a mode of societal governance. Public Management. An International Journal of Research and Theory 2 (3): 359-378.

Krasner, Stephen D. 2009. Power, the sate, and sovereignty. Essays on international relations. Abingdon: Routledge.

Lackner, Michael. 2004. Anmerkungen zur historischen Semantik von China, Nation und chinesischer Nation im modernen Chinesisch. In: Turk, Horst u.a. (Hrsg.) (2004): Kulturelle Grenzziehungen im Spiegel der Literaturen: Nationalismus, Regionalismus, Fundamentalismus, ed. Horst Turk et al., 323-338, Göttingen: Wallstein Verlag.

Lan, Chun, and Dengmei Jia. 2016. A cognitive approach to tian (heaven) in ancient and modern Chinese. Journal of China in Comparative Perspective 2 (1): 56-80.

Legge, James. 1985. The Chinese classics. Vol. I. Reprint. Taipei: Southern Material Center.

Li, Chensyng. 2006. The Confucian ideal of harmony. Philosophy East and West 56 (4): 583-603.

Li, Shenzhi. 1999. Reflections on the Concept of the Unity of Heaven and Man ("tian ren he yi"). In Chinese Thought in a Global Context. A Dialogue Between Chinese and Western Philosophical Approaches, ed. Karl-Heinz Pohl, 115-130. Leiden: Brill.

Lü Xiaobo, Elizabeth J. Perry (eds.). 2015. The Danwei. Changing Chinese Workplace in Historical and Comparative Perspective. Abengdon: Routledge.

Machle, Edward J. 1993. Nature and heaven in the Xunzi. A study of the tian Lun. Albany. NY: State University of New York Press.

Markus, Hazel Rose, and Shinobus Kitayama. 1991. Culture and the self: Implications for cognition, emotion, and motivation. Psychological Review 98 (2): 224-253.

McMaster, H. R., and Gary D. Cohn. 2017. America first Doesn't mean America alone. The Wall Street Journal, May 30, 2017.

McVeigh, Brian J. 1998. The nature of the Japanese state. Rationality and rituality. London: Routledge.

Müller, Reimar. 1987. Polis und Res Publica Studien zum antiken Gesellschafts- und Geschichtsdenken. Weimar: Böhlau.

Nagle, D. Brendan. 2006. The household as the Foundation of Aristotle's polis. Cambridge and New York: Cambridge University Press.

Nakane, Chie. 1970. Japanese society. Berkeley, CA: University of California Press.

Qin, Yaqing. 2016. A relational theory of world politics. International Studies Review 18 (1): 33-47.

Richter, Daniel S. 2011. Cosmopolis. Imagining Community in Late Classical Athens and the early roman empire. Oxford: Oxford University Press.

Rošker, Jana S. 2013. The concept of harmony in contemporary P. R. China and in modern Confucianism. Asian Studies, 1 (17), 2: 3-20.

Runciman, William G. 1990. Doomed to extinction. The polis as an evolutionary dead-end. In The Greek City from Homer to Alexander, ed. Oswyn Marray and Simon Price, 347-367. Oxford: Clarendon Press.

Schaaf, Judy. 2001. Jia, "Family", and the Chinese House. In An Introduction to the Chinese Culture through the Family, ed. Howard Giskin and Bethy S. Walsh, 163-194. Albany, NY: State University of New York Press.

Tian, Hailong. 2014. Differing Translation, Contested Meanings: A Motor for the 1911 Revolution in China? In A Global Conceptual History of Asia, 1860-1940, ed. Hagen Schulz-Forberg, 43-60. Abingdon: Routledge.

Vogelsang, Kai. 2012. Chinese "society". History of a troublesome concept. Oriens Extremus 51 (7): 157-182.

Wang, Ban. 2017. Chinese visions of world order. Tianxia, culture, world politics. Durham: Duke University Press.

Wang, Fei-Ling. 2005. Organizing through division and exclusion. China's Hokou system. Stanford: Stanford University Press.

Wang, Mingming. 2012. All under heaven (tianxia): Cosmological perspectives and political ontologies in pre-modern China. Journal of Ethnographic Theory 2 (1): 337-383.

Weber-Schäfer, Peter. 1968. Oikumene und Imperium, Studien zur Ziviltheologie des chinesischen Kaiserreiches. München: Paul List Verlag.

Welwei, Karl-Wilhelm. 1998. Die griechische polis. 2nd ed. Aufl, Stuttgart: Franz Steiner.

Wildberger, Jula. 2006. Seneca und die Stoa: Der Platz des Menschen in der Welt. Band 1: Text. Berlin: Walter de Gruyter. Yao, Xinzhong. 2014. An eco-ethical interpretation of Confucian Tianren Heyi. Frontiers of Philosophy in China 9 (4): 570-585.

Young, Jason. 2013. China's Hokuo system. Markets, migrants and institutional change. Basingstoke: Palgrave Macmillan.

Yü, Ying-shih. 2016. Chinese History and Culture, Volume I: Sixth Century B.C.E. to Seventeenth Century. New York: Columbia University Press.

Zhang, Xuezhi. 2017. Ecological consciousness and the conscience in the writings of Wang Yangming. In Reconceptualizing Confucian philosophy in the $21^{\text {st }}$ century, ed. Xinzhong Yao, 339-354. Singapore: Springer Nature.

Zhao Tingyang 赵汀阳. 2005. The Tianxia System: An Introduction to the Philosophy of a World Institution (Tianxia Tixi: Shijie zhidu zhexue daolun 天下体系:世界制度哲学导论), Nanjing: Jiangsu Jiaoyu Chubanshe.

Zhao, Tingyang. 2006. Rethinking empire from a Chinese concept 'all-under-heaven' (tian-xia). Social Identities 12 (1): 29-41.

Zhao Tingyang. 2009. A political world philosophy in terms of all-under-heaven (tian-xia). Diogenes, 56, 1. S1: 5-8.

Zhao, Tingyang. 2012. All-Under-Heaven and Methodological Relationism: An Old Story and New World Peace. In Contemporary Chinese Political Thought. Debates and Perspectives, ed. Fred Dallmayr and Tingyang Zhao, 46-66. Lexington: University of Kentucky Press. 